\title{
COMPARISON EFFECT OF GEL AND SPRAY AIR FRESHENER EXPOSURE ON DIAMETER OF SEMINIFEROUS TUBULES AND CONCENTRATION SPERM OF WHITE RATS (Rattus norvegicus)
}

\author{
Yuningtyaswari', Noor Zulkhah² \\ 'Departement of Histology Faculty of Medicine and Health Science, Universitas Muhammadiyah Yogyakarta \\ ${ }^{2}$ Departement of Fisiology Faculty of Medicine and Health Science, Universitas Muhammadiyah Yogyakarta \\ Jalan Lingkar Selatan Tamantirto Kasihan Bantul DIY 55183 \\ Email : yuningtyas_fkumy@yahoo.com
}

\section{INTRODUCTION}

Indoor air pollution is the fifth most common health risk to the environment (USEPA, 2011). Indoor air pollution among others came from deodorizer such as air freshener. Chemicals that can be found in the air freshener include: benzene, formaldehyde, limonene, even phthalate (Hanke, et al, 2006). Such compounds are generally harmful to the reproductive system by interfering with the endocrine system of the testes, the cells Leydig. Chemical composition varies depending on the form of air freshener or manufacturer. Air freshener also emits volatile organic compound (VOC) room deodorizer gel and liquid (spray) is widely used in society. Consumers are not aware of any risk to the health of the use of air freshener. Aim of this study was to compare the effect of gel and spray air freshener exposure to the diameter of the seminiferous tubules and sperm concentration in male Rattus norvegicus.

\section{MATERIALS AND METHODS}

This study was purely experimantal approach-post-only control-group design. The subjects of this study were 18 white rats (Rattus norvegicus) male which were divided into 3 groups : gel group which was exposed by gel air freshener for 8 hours / day, spray group which was exposed by spray air freshener for 8 hours / day and control group without any treatment. Exposure air freshener was given for 30 days, consecutively. This research used air freshener from the same manufacturer scented lemon. On day 31, subjects were sacrificed and sperm concentration was calculated. Testes were taken for further histological preparations made by the method of paraffin blocks with Hematoxylin Eosin (HE) staining technique. Seminiferous tubule diameter was measured using the software Opti Lab on 10 field of view in each histological preparations Data were analyzed using one way ANOVA.

\section{RESULTS AND DISCUSSION}

Results for both measurement and histology of seminiferous tubules is presented in Table 1, Figure 1.2 and 3.

In general, the results of this study showed a negative effect of exposure to the air freshener histology reproductive system, particularly the seminiferous tubules of the testes and sperm concentration. Air freshener has a negative impact on health, particularly reproductive system because it contains dangerous chemical compounds, among others phthalates, 
Table 1. Diameter of the seminiferous tubules of subjects $(\mu \mathrm{m})$

\begin{tabular}{cll}
\hline Number. & Treatment & Average \pm SD \\
\hline 1. & Control & $225,8875 \pm 9,2805^{\mathrm{c}}$ \\
2. & Gel & $202,3667 \pm 6,4450^{\mathrm{a}}$ \\
3. & Spray & $214,0333 \pm 5,0212^{\mathrm{b}}$ \\
\hline
\end{tabular}

Description:

One Way ANOVA results showed a significant difference between the groups being compared, with $F=16285$ and $p=0.0001$. PostHoc Duncan test results indicated a difference between groups $\left({ }^{\mathrm{a}, \mathrm{b}, \mathrm{c}}\right) \mathrm{p}=0.05$.

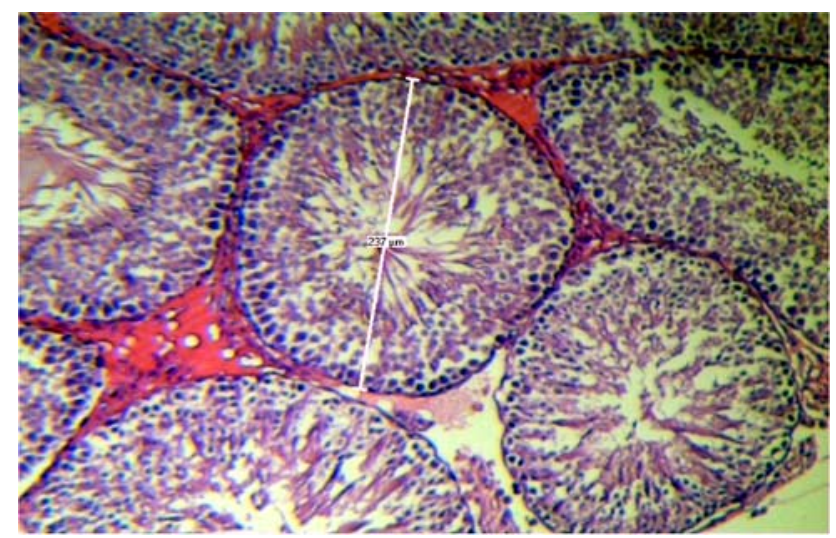

Figure 1. Histology of the seminiferous tubules of the control group subjects (HE, 100x)

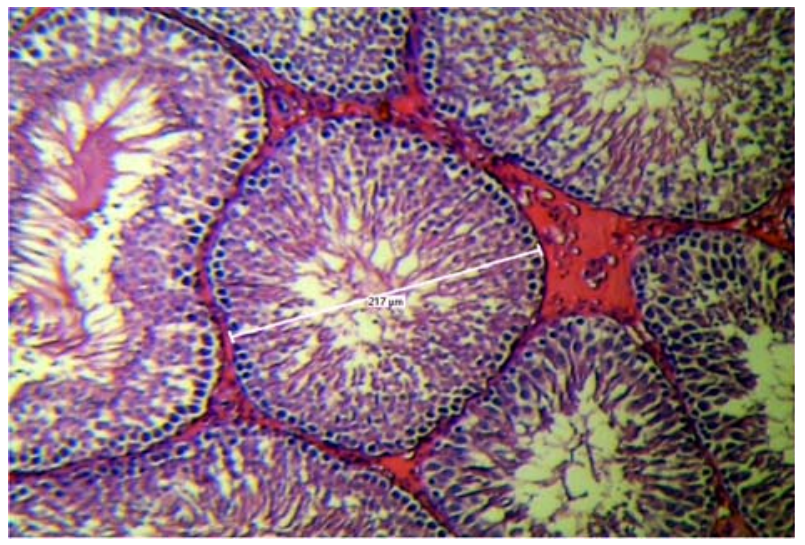

Figure 2. Histology of the seminiferous tubules of the spray group subjects (HE, 100x)

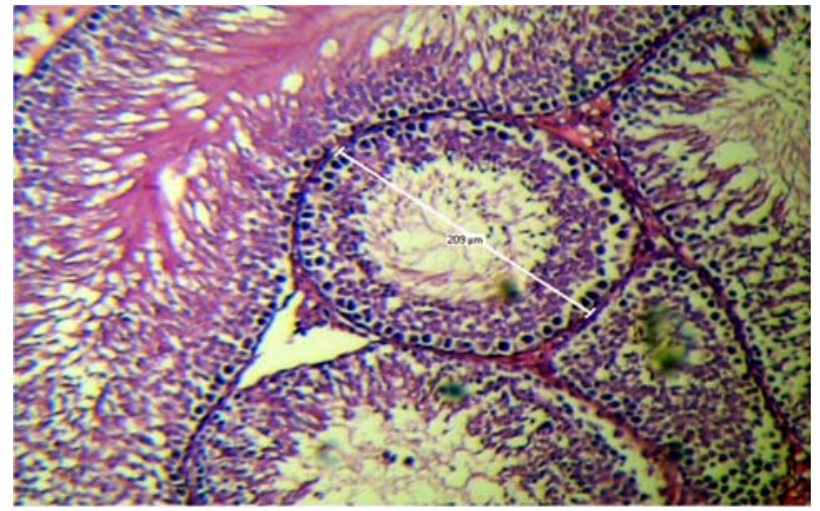

Figure 3. Histology of the seminiferous tubules of the gel group subjects (HE, 100x) 
Result of concentration of sperm count in this study is presented in Table 2.

Table 2. Sperm concentration of subjects $/ 10 \mu \mathrm{L}$ of semen

\begin{tabular}{ccc}
\hline Number. & Kelompok & average \pm SD \\
\hline 1. & Control & $710000,00 \pm 258786,00$ \\
2. & Gel & $457500,00 \pm 116823,00$ \\
3. & Spray & $590833,33 \pm 61677,93$ \\
\hline
\end{tabular}

One Way ANOVA showed no significant difference between the groups being compared, with $\mathrm{F}=34.02$

acetaldehyde, styrene toluene, chlorbenzene, paradichlorobenzene, formaldehyde and benzene. Air freshener also emits volatile organic compounds (VOC).

Phthalate absorption is directly absorbed through inhalation on respiratory system. It absorbed as DEHP and circulates in the blood without hydrolysis as the oral route. Dermal absorption lines can only absorb dissolved DEHP. Ethanol is typically a solvent would facilitate the entry of DEHP which then circulates in the blood directly to the reproductive system as a target (Bhattacharya et al., 2004). Phthalate affects the reproductive system that is as confounding endocrine system in the testis. Pthtalate target is a hormone-producing Leydig cell testosterone resulting in reduced seminiferous tubule diameter, fertility, densitan sperm motility, and testicular weight (Nguyen et al.,2010).

Formaldehyde affects Relaxin-like factor (RLF), also known as the Leydig cell insulinelike factor (Ley-IL), is a circulating hormone, synthesized by mammalian gonadal and circulated in the bloodstream. RLF is detected as a protein at high levels in testis Leydig cells mature and the fetus. RLF serves as the agency responsible for testicular descent in the early days of life and anti-appoptosis in male germ cells. RLF also as a biomarker for Leydig cells (Gules \& Eren, 2010).

Negative effects of air freshener can also be delivered trough free radical mechanism, related to the content of formaldehyde and benzene derivatives. This is in line with result of previous study of Heryani, et.al. (2011) which states that formaldehyde exposure causes increased reactivity of Reactive Oxygen Substence (ROS) which will damage DNA, proteins and lipids constituent of cell membranes. These circumstances lead to decrease activity of the enzyme superoxide dismutase (SOD), which acts as an enzymatic antioxidant which is involved in the inactivation of the main scavenger and termination of oxygen free radicals (Heryani et al., 2011).

Potential arrest of reactive oxygen compounds in the normal reproductive tract demonstrated by sufficient levels of antioxidants SOD, catalase, glutathione, vitamin $\mathrm{E}$, and $\mathrm{C}$ and á-carotene. When there is an imbalance between antioxidant levels and the number of reactive oxygen compounds will be a condition called oxidative stress and cause a decline in fertility (Heryani et al., 2011).

Results of this study proved that the air freshener exposure can affect the male reproductive system are indicated with a histological picture size reduction of testicular seminiferous tubule diameter and decreased the concentration of spermatozoon. In general, it can be concluded that the gel air freshener has higher effect on reproduction system than spray. 


\section{REFERENCES}

Bhattacharya, N., J.M. Dufour, M.N. Vo, J. Okita, R. Okita, and K.H. Kim. 2005. Differential Effecct of Phthalates on the Testis and Liver. Biol Reprod, Mar;72(3):745-54. Epub 2004 Nov 24 http://www.ncbi.nlm.nih.gov/pubmed/15564602. accessed on June 302011

Gules, E., and O. Eren. 2010. The Effect of Xylene and Formaldehyde Inhalation on Testicular Tissue in Rats. Asian-Aust. J. Anim. Sci.Vol. 23, No. 11 : 1412 - 1420. http:// www.ajas.info/Editor/manuscript/upload/23-185.pdf. accessed on April 152012.

Hanke, W., B. Jansson, H. Komulainen, O. Ladefoged, I. Mangelsdorf, A. Steenhout. 2007. Opinion on Risk Assesment on Indoor Air Quality. http://ec.europa.eu/health/ph_risk/ committees/04_scher/docs/scher_o_055.pdf, accessed on March 312012.

Heryani, L.G.S.S., N.N.W. Susari, I.M. Kardena, D.N.D.I. Laksmi. 2011. Pendedahan Formalin Menghambat Proses Spermatogenesis pada Mencit. Jurnal Veteriner Vol. 12 No. 3: 214-220 ISSN : $1411-8327$.

Nguyen, T.T., E.M. Jung, H. Yang, S.H. Hyun, K.C. Choi. 2010. Potential Endokrin Disrupting Effects of Phtalates in In vitro and In Vivo Models. J. Emb. Trans. Vol. 25, No.4, pp.207213. files.vienthuy-nivr.webnode.com, accessed on March 312012.

USEPA. United State Environmental Protection Agency . 2011. The Inside Story: A Guide to Indoor Air Quality. Publication and Resourches. http://www.epa.gov/iaq/pubs/ insidestory.html. accessed on April 252011 